\title{
Spatial distribution of Coleoptera (Insecta) in the valley forests of the Ussuri Nature Reserve (South Primorye, Russia)
}

\author{
Alexander V. Kuprin*, Victorya A. Kharchenko \\ Ussuri Nature Reserve, Far East Branch, Russian Academy of Sciences, Ussuriysk, Russia; \\ *Corresponding Author: kyprins@mail.ru
}

Received 1 October 2013; revised 1 November 2013; accepted 8 November 2013

Copyright (C 2013 Alexander V. Kuprin, Victorya A. Kharchenko. This is an open access article distributed under the Creative Commons Attribution License, which permits unrestricted use, distribution, and reproduction in any medium, provided the originnal work is properly cited.

\begin{abstract}
Five habitat types have been studied in the valley forests of the Ussuri Nature Reserve. The cluster analysis was used to distinguish two types of clusters. The first one combines the anthropogenically modified forest plot, the margin, and the plot of a typical valley broad-leaved tree, while the second one combines the oak forest and the coniferous and broad-leaved valley forest. The greatest number of volant Coleoptera species were observed at the margin of the broad-leaved forest.
\end{abstract}

Keywords: Coleoptera; Imago; Spatial Distribution; Ussuri Nature Reserve; South Primorye; Russia

\section{INTRODUCTION}

Coleoptera (Insecta) is one of the most numerous and ecologically versatile insect orders. The beetles can be found in almost all geographical zones and inhabit most terrestrial ecosystems. Large beetle populations, occurrence in different habitats, and sensitivity to alterations in the environmental situation allow one to use them as a model group to study the structures of communities inhabiting the disturbed and control areas. Herpetobiont Coleoptera, which can actively move over the soil surface, is currently studied in Primorsky Krai. Special attention is paid to the seasonal structural aspects of terrestrial Coleoptera populations in cedar-broad-leaved forests on the western macroslope of the Sikhote-Alin mountain range [1,2]. The population of volant Coleoptera in Russian Far East has not been studied previously, although this type of research has been carried out for some areas [3-11]. It is of special interest to study the population of volant Coleoptera in natural ecosystems that had not been subjected to anthropogenic impact (forests of the Ussuri Nature Reserve).

This work was aimed at determining the species composition and the features of spatial distribution of Coleoptera imago using window traps by the example of the Ussuri Nature Reserve.

\section{MATERIALS AND METHODS}

The Coleoptera were collected in 2011-2012 in valley broad-leaved forests of the Ussuri Nature Reserve every ten days during the period between April and October. Window traps mounted onto trunks of wind damaged trees were used to collect the beetles [12]. Window traps were made as follows: two planks $(100 \times 100 \times 100 \mathrm{~mm})$ were nailed to the trunk at a distance of $400 \mathrm{~mm}$ from each other; $400 \times 500 \mathrm{~mm}$ glass was placed vertically on the planks; a polyethylene tray filled with preservative solution (a 3\% formalin solution was used as a preservative) was stretched under the glass. The traps were mounted at five model plots (Figure 1).

\section{RESULTS AND DISCUSSION}

A total of 2177 Coleoptera belonging to 27 families, 61 orders, and 79 species were collected in 2011-2012 (Table 1). The representatives of the families Staphylinidae (11 species from 6 genera), Cerambycidae (7 species from 7 genera), Elateridae ( 7 species from 5 genera), and Scarabaeidae (6 species from 5 genera) were most diverse; the rest of the families were represented by $1-4$ species.

The greatest level of species diversity was observed on the margin of the ash and elm forest, while the lowest 
one was observed in an indigenous cedar forest with elms and ashes (Table 1). The overall number of species detected at the model plots during the entire study period was 79 and 14, respectively. The reason for that is that the greatest number of Coleoptera species concentrate on open and thinned plots. Moreover, the well-known marginal effect manifests itself: a trend toward increasing variety and density of organisms is observed in the ecotone (in this case, it is the transition from a forest to a meadow). The species diversity in ecotones is formed by representatives of the adjacent ecosystems.

Numerous representatives of Dendroxena sexcarinata, Oiceoptoma thoracicum (Silphidae), Cucujus haematodes (Cucujudae), Prismognathus dauricus (Lucanidae) were observed at the forest margin.

48 species ( $60.8 \%$ of the total number of species) were recorded in the valley ash and elm forest after felling.

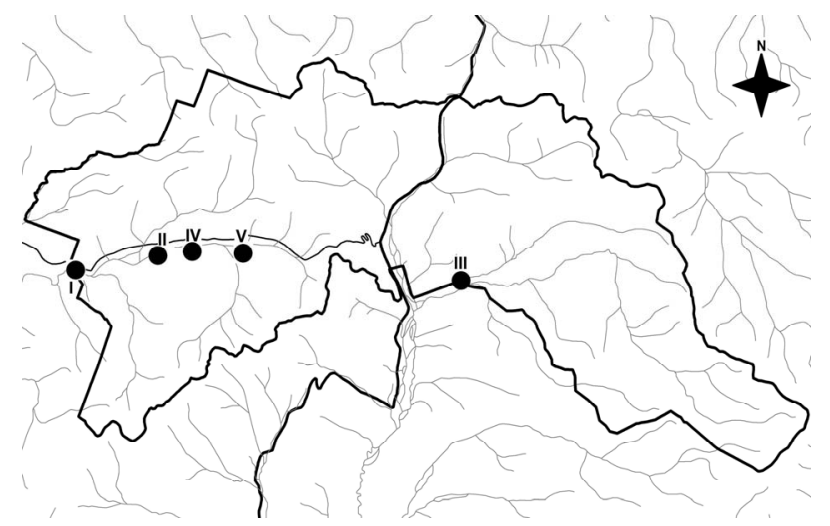

Figure 1. A schematic map of the provisions of the model plots in the Ussuri Nature Reserve. I-valley ash and elm forest after maintenance felling; II-margin of an ash and elm forest; IIIoak forest with the Korean pine; IV_-indigenous valley ash and elm forest; $\mathrm{V}$-indigenous cedar forest with ashes and elms.

Table 1. Spatial distribution of Coleoptera imago in valley forests in the Ussuri Nature Reserve.

\begin{tabular}{|c|c|c|c|c|c|}
\hline \multirow{2}{*}{ Species } & \multicolumn{5}{|c|}{ Model plots } \\
\hline & $\mathrm{I}$ & II & III & IV & $\mathrm{V}$ \\
\hline \multicolumn{6}{|l|}{ Familia Rhysodidae } \\
\hline Rhysodes comes & 1 & 7 & - & 3 & - \\
\hline \multicolumn{6}{|l|}{ Familia Carabidae } \\
\hline Tachyta nana & 11 & 17 & 5 & 19 & 8 \\
\hline \multicolumn{6}{|l|}{ Familia Histeridae } \\
\hline Hister sibiricus & - & 12 & 11 & 10 & 8 \\
\hline Hister unicolor & 8 & 9 & 6 & 4 & 2 \\
\hline Hololepta amurensis & 3 & 10 & 2 & - & - \\
\hline Hololepta plana & 2 & 6 & 4 & 5 & 1 \\
\hline \multicolumn{6}{|l|}{ Familia Silphidae } \\
\hline Dendroxena sexcarinata & 45 & 52 & 14 & 16 & 18 \\
\hline Nicrophorus praedator & - & 9 & - & - & - \\
\hline Nicrophorus quadripunctatus & 9 & 11 & - & 6 & 14 \\
\hline Oiceoptoma subrufum & 1 & 11 & 12 & - & - \\
\hline Oiceoptoma thoracicum & 25 & 47 & 16 & 18 & 30 \\
\hline Oxyporus aequicollis & 5 & 10 & - & - & - \\
\hline Oxyporus maxillosus & - & 11 & - & - & - \\
\hline Oxyporus procerus & 4 & 10 & - & - & 1 \\
\hline Siagonium vittatum & 3 & 5 & - & 1 & - \\
\hline Tachinus bipustulatus & 12 & 9 & - & - & - \\
\hline Tachinus marginatus & 4 & 8 & - & - & - \\
\hline Ontholestes tesselatus & - & 12 & - & - & - \\
\hline Ontholestes simulator & - & 7 & - & - & - \\
\hline Philonthus cyanipennis & 4 & 11 & - & - & - \\
\hline Platydracus aureofasciatus & 6 & 9 & - & - & - \\
\hline Platydracus mortuorum & 7 & 8 & - & - & - \\
\hline \multicolumn{6}{|l|}{ Familia Lucanidae } \\
\hline Hemisodorcus rubrofemoratus & - & 5 & - & - & - \\
\hline Lucanus maculifemoratus & - & 7 & 11 & - & - \\
\hline Macrodorcas recta & - & 7 & - & - & - \\
\hline Prismognathus dauricus & - & 25 & - & 18 & - \\
\hline Holotrichia diomphalia & 7 & 11 & 2 & 1 & 1 \\
\hline Holotrichia sichotana & 5 & 9 & 1 & 1 & 1 \\
\hline Lasiotrichius succinctus & - & 12 & - & 9 & - \\
\hline Onthophagus uniformis & - & 2 & - & 1 & - \\
\hline Osmoderma davidis & - & 4 & - & 2 & - \\
\hline Protaetia marmorata & - & 7 & - & - & - \\
\hline \multicolumn{6}{|l|}{ Familia Buprestidae } \\
\hline Lamprodila bellula & - & 3 & - & - & - \\
\hline
\end{tabular}




\section{Continued}

\begin{tabular}{|c|c|c|c|c|c|}
\hline Familia Eucnemidae & & & & & \\
\hline Microrhagus foveolatus & - & 12 & - & - & - \\
\hline Microrhagus mystagogus & - & 18 & - & - & - \\
\hline Familia Throscidae & & & & & \\
\hline Aulonothroscus longulus & - & 8 & - & - & - \\
\hline Familia Elateridae & & & & & \\
\hline Ampedus pomonae & 3 & 9 & 1 & 14 & - \\
\hline Ampedus pomorum & 19 & 10 & 1 & 15 & - \\
\hline Denticollis cinctus & 27 & 19 & 1 & 12 & - \\
\hline Elater luctuosus & 11 & 17 & - & 2 & - \\
\hline Lacon altaicus & 19 & 14 & - & 9 & - \\
\hline Melanotus castanipes & 12 & 21 & - & 14 & - \\
\hline Melanotus pygmaeus & 14 & 19 & - & 9 & - \\
\hline Familia Lycidae & & & & & \\
\hline Plateros kurentzovi & - & 1 & - & 1 & - \\
\hline Familia Lymexylonidae & & & & & \\
\hline Elateroides dermestoides & 11 & 26 & 9 & 15 & 18 \\
\hline Familia Monotomidae & & & & & \\
\hline Rhizophagus japonicus & 10 & 3 & - & 14 & - \\
\hline Familia Silvanidae & & & & & \\
\hline Silvanus bidentatus & 14 & 21 & - & - & - \\
\hline Familia Cucujidae & & & & & \\
\hline Cucujus haematodes & 47 & 65 & 14 & 48 & 14 \\
\hline Familia Endomychidae & & & & & \\
\hline Mycetina marginalis & - & 21 & - & - & - \\
\hline Familia Melandryidae & & & & & \\
\hline Melandrya mongolica & - & 18 & - & - & - \\
\hline Phloiotrya bellicosa & - & 4 & - & - & - \\
\hline Familia Mordellidae & & & & & \\
\hline Hoshihananomia auromaculata & - & 12 & - & - & - \\
\hline Familia Zopheridae & & & & & \\
\hline Phellopsis amurensis & - & 2 & - & - & - \\
\hline Familia Tenebrionidae & & & & & \\
\hline Misolampidius tentyrioides & 15 & 30 & - & 18 & - \\
\hline Neatus ventralis & - & 19 & - & 12 & - \\
\hline Familia Oedemeridae & & & & & \\
\hline Ischnomera abdominalis & 8 & 10 & - & - & - \\
\hline Familia Pyrochroidae & & & & & \\
\hline Pseudopyrochroa lateraria & 17 & 10 & - & 14 & - \\
\hline Schizotus fuscicollis & - & 12 & - & 2 & - \\
\hline Familia Cerambycidae & & & & & \\
\hline Callipogon relictus & - & 11 & - & 1 & \\
\hline Eutetrapha metallescens & 27 & 22 & - & 11 & - \\
\hline Exocentrus marginatus & - & 2 & - & 1 & - \\
\hline Leptura thoracica & 18 & 11 & - & 14 & - \\
\hline Menesia sulphurata & 17 & 15 & - & 3 & - \\
\hline Oupyrrhidium cinnabarinum & 5 & 9 & - & 8 & - \\
\hline Pterolophia multinotata & - & 3 & - & - & - \\
\hline Familia Rhynchitidae & & & & & \\
\hline Byctiscus princeps & 7 & 6 & 1 & 2 & - \\
\hline Familia Curculionidae & & & & & \\
\hline Fronto capiomonti & 11 & 9 & - & - & - \\
\hline Magdalis koltzei & - & 8 & - & - & - \\
\hline Orchestes mutabilis & 6 & 8 & - & - & - \\
\hline Orchestes ruber & 9 & 11 & - & - & - \\
\hline Phloeophagus orientalis & - & 4 & - & - & - \\
\hline Familia Scolytidae & & & & & \\
\hline Scolytus butovitschi & 1 & 3 & - & - & - \\
\hline Scolytus jacobsoni & 5 & 18 & - & 15 & 3 \\
\hline Scolytus japonicus & 3 & 11 & - & 4 & - \\
\hline Scolytus semenovi & 2 & 9 & - & 1 & - \\
\hline Scolytus trispinosus & 2 & 7 & - & 2 & - \\
\hline Xyleborinus saxesenii & 4 & 7 & - & 7 & - \\
\hline Total species: & 48 & 79 & 18 & 44 & 14 \\
\hline Total individuals: & 523 & 999 & 127 & 395 & 133 \\
\hline
\end{tabular}

Note: The species are listed in alphabetical order. I—valley ash and elm forest after maintenance felling; II—margin of an ash and elm forest; III—oak forest with the Korean pine; IV—indigenous valley ash and elm forest; V—indigenous cedar forest with ashes and elms. 
Four species are numerous at this plot: Dendroxena sexcarinata, Denticollis cinctus, Cucujus haematodes, Eutetrapha metallescens.

44 Coleoptera species were observed in the indigenous valley elm and ash forest, which makes $55.7 \%$ of the total number of species in this insect group. Callipogon relictus and Phellopsis amurensis are the specific species.

18 Coleoptera species were recorded in the oak forest with the Korean pine. Silphidae, Cucujidae, and Lucanidae are the most numerous families in terms of collected specimens.

The general levels of species diversity at the margin of the elm and ash forest, indigenous valley elm and ash forest, and indigenous ash and elm forest after maintenance felling are similar to each other (Table 2). The common feature of the Coleoptera clusters in the aforementioned habitats is the relatively large number of Coleoptera species. The number of beetles is smaller under the conditions of grass, as well as tree and shrub, vegetation (oak forest with the Korean pine) and in strongly shadowed habitats characterized by complex structure (indigenous cedar forest with the elms and ashes). The more homogenous domination structure $(d=0.07-0.13)$ is typical of most valley habitats in the nature reserve, except for the indigenous cedar forest (Table 2), where reduced diversity and increased degree of domination has been observed ( $d=0.23$ ).

The comparison of the trophic clusters of Coleoptera imago at different model plots has demonstrated that despite the difference in the number of species, the composition of the trophic clusters in the valley ash and elm forest after maintenance felling, at the margin of the elm and ash forest, and in the indigenous valley elm and ash forest is homogeneous to an appreciable extent (Figure 2).

The relationship between phytophages in these habitats varies from $52.2 \%$ to $63.7 \%$; the greatest number

Table 2. Indicators of species diversity of Coleoptera in the model plots in the Ussuri Nature Reserve.

\begin{tabular}{ccccccc}
\hline \multirow{2}{*}{ Model plots } & \multicolumn{5}{c}{ Indicators of species diversity } \\
\cline { 2 - 7 } & $\mathrm{S}$ & $\mathrm{N}$ & $\mathrm{D}_{\mathrm{Mn}}$ & $\mathrm{D}_{\mathrm{Mg}}$ & $\mathrm{D}_{\mathrm{Sm}}$ & $\mathrm{d}$ \\
\hline I & 48 & 523 & 2.19 & 7.83 & 0.036 & 0.09 \\
II & 79 & 999 & 2.50 & 11.29 & 0.020 & 0.07 \\
III & 18 & 127 & 1.60 & 3.50 & 0.083 & 0.13 \\
IV & 44 & 395 & 2.21 & 7.19 & 0.040 & 0.12 \\
V & 14 & 133 & 1.21 & 2.66 & 0.122 & 0.23 \\
\hline
\end{tabular}

Note: The designation of the model plots is identical to that in Table 1. Snumber of species, $\mathrm{N}-$ number of specimens, $\mathrm{D}_{\mathrm{Mn}}-$ the Menchinik index, $\mathrm{D}_{\mathrm{Mg}}$ - the Margalef index, $\mathrm{D}_{\mathrm{Sm}}$-the Simpson index, $\mathrm{d}$-the Berger-Parker index.

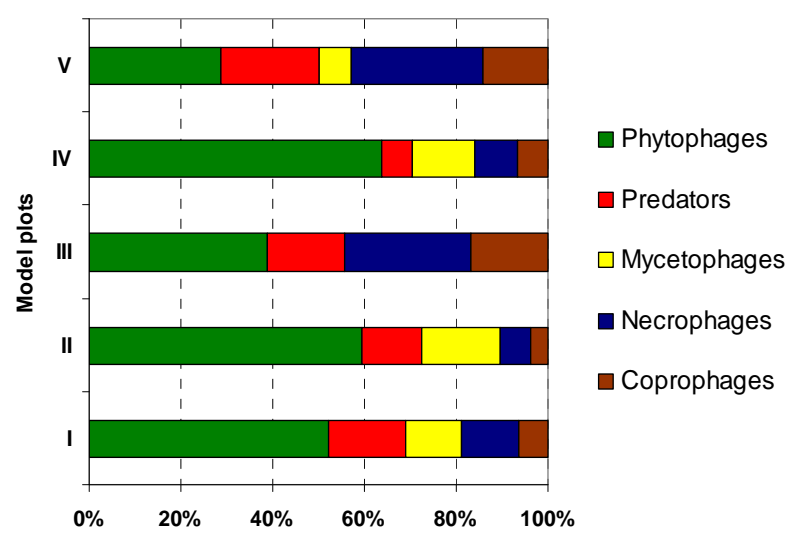

Figure 2. The ratio between trophic groups of imago at the model plots (I-valley ash and elm forest after maintenance felling; II—margin of the elm and ash forest; III—oak forest with the Korean pine; IV-indigenous valley elm and ash forest; $\mathrm{V}$-indigenous cedar forest with the elms and ashes).

being observed in the indigenous valley elm and ash forest. The percentage of antophages in the ash and elm forest after maintenance felling is twice as low as that at the forest margin and in the indigenous elm and ash forest (Figure 2). It should be mentioned that no antophages have been detected in the oak and indigenous cedar forest, which can be attributed to the lack of feeding objects.

Coprophages and necrophages are dominating among the species inhabiting the oak and indigenous cedar forests; their total percentage is $44.4 \%$ and $42.9 \%$, respecttively. The percentage of phytophages in these habitats is smaller: $38.9 \%$ and $28.6 \%$, respectively.

An analysis of the similarity of the species compositions of Coleoptera insects at the model plots has demonstrated that two clusters can be distinguished at low similarity levels (0.28) (Figure 3).

The first cluster combines the valley ash and elm forest after maintenance felling, the margin of the elm and ash forest, and the indigenous valley elm and ash forest, while the second cluster combines the oak forest and the indigenous cedar forest with the elms and ashes (Figure 3 ). The fact that the elm and ash forest after maintenance felling and the forest margin have been combined into a single cluster is most probably caused by high illumination level and high species diversity among plants resulting in high species diversity of Coleoptera. The cluster combining the ash and elm forest after maintenance felling and the forest margin at 0.55 similarity level borders with the indigenous valley elm and ash forest, with the mean index of the number of Coleoptera species that had been caught with window traps in a given habitat. The combination of the oak forest with the cedar and the valley cedar forest into a single cluster is caused by the depleted species composition of Coleoptera in these habitats. 


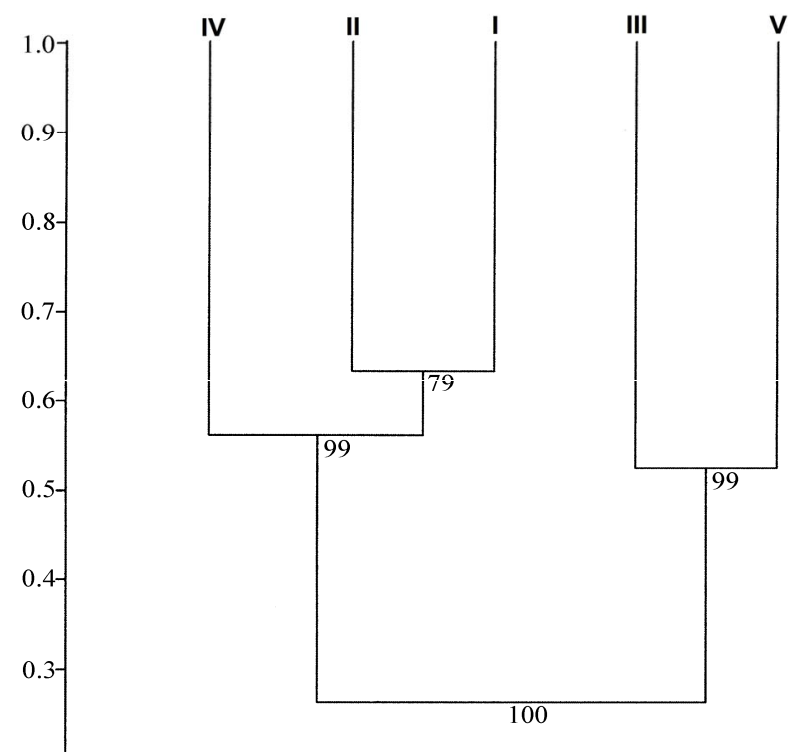

Figure 3. The similarity between the Coleoptera populations of the model plots (UPGMA, Jaccard coefficient). Designation of the model plots is identical to that in Figure 2.

\section{CONCLUSION}

Five habitat types have been studied in the valley forests of the Ussuri Nature Reserve. The cluster analysis was used to distinguish two types of clusters. The first one combines the anthropogenically modified forest plot, the margin, and the plot of a typical valley broad-leaved tree, while the second one combines the oak forest and the coniferous and broad-leaved valley forest. The greatest number of volant Coleoptera species was observed at the margin of the broad-leaved forest, while the smallest number was observed under the canopy of the coniferous-broad-leaved forest.

\section{ACKNOWLEDGEMENTS}

The authors are grateful to N. B. Nikitsky (Zoological Museum, Moscow State University, Moscow), B. G. Bezborodov (Amur Division of the Botanical Garden-Institute, FEB RAS, Blagoveshchensk) for the assistance in identifying the material and to S. A. Shabalin (Institute of Soil Biology, FEB RAS, Vladivostok) for the assistance in statistical processing of the data. The work was supported in part by the Russian-Korean project "Ecological and Biological Study of Callipogon relictus Sem”. No. 2010-09-21.

\section{REFERENCES}

[1] Shabalin, S.A. (2008) Features of habitat distribution of ground beetles and burying beetles (Coleoptera: Carabidae, Silphidae) in the northern part of the Southern Sikhote-Alin mountain range. Eurasian Entomological Journal, 3, 207-212.

[2] Shabalin, S.A. and Lafer, G.Sh. (2010). Summer population of herpetobiont Coleoptera (Coleoptera: Carabidae, Silphidae, Scarabaeidae) in valley forests of the Middle Sikhote-Alin range. Readings in Honor of A.I. Kurentsova, 21, 71-81.

[3] Barsulo, C.Y. and Nakamura, K. (2011) Abundance and diversity of flying beetles (Coleoptera) collected by window traps in Satoyama Pine Forests in Noto Peninsula, Japan, with special reference to the management conditions: A family level analysis. Far Eastern Entomologist, 222, 1-23.

[4] Chung, A.Y.C. (2004) Vertical stratification of beetles (Coleoptera) using flight intercept traps in a lowland rainforest of Sabah, Malaysia. Sepilok Bulletin, 1, 29-41.

[5] Chung, A.Y.C., Eggleton, P., Speight, M.R., Hammond, P.M. and Chey, V.K. (2001) Variation in beetle (Coleoptera) diversity at different heights of the tree canopy in a forest and forest plantation in Sabah, Malaysia. Journal of Tropical Forest Science, 13, 369-385.

[6] Moran, V.C. and Southwood, T.R.E. (1982) The guild structure of arthropod communities in trees. Journal of Animal Ecology, 51, 289-306. http://dx.doi.org/10.2307/4325

[7] Schowalter, T.D. and Giano, L.M. (1998) Vertical and seasonal variation in canopy arthropod communities in an old-growth conifer forest in southwestern WA, USA. Bulletin of Entomological Research, 88, 633-640. http://dx.doi.org/10.1017/S0007485300054304

[8] Shaw, D.C. (2004) Vertical organization of canopy biota: Forest canopies. Elsevier, Amsterdam.

[9] Sutton, S.L., Ash, C.P. and Crundy, A. (1983) The vertical distribution of flying insects in the lowland rain forest of Panama, Papua New Guinea and Brunei. Zoological Journal of the Linnean Society, 78, 287-297. http://dx.doi.org/10.1111/j.1096-3642.1983.tb00868.x

[10] Trisnawati, I. and Nakamura, K. (2008) Abundance, diversity and distribution of above-ground arthropods collected by window traps from satoyama in Kanazawa, Japan: An order level analysis. Far Eastern Entomologist, 181, 1-23.

[11] Turton, S.M. and Siegenthaler, D.T. (2004) Immediate impacts of a severe tropical cyclone on the microclimate of a tropical rainforest canopy in northeast Australia. Journal of Tropical Ecology, 20, 6-583. http://dx.doi.org/10.1017/S0266467404001622

[12] Samkov, M.I. and Chernyshev, V.B. (1983) Window traps and possibilities of their use in entomology. Zoological Journal, 10, 1571-1574. 